\title{
Talen in Beweging
}

Citation for published version (APA):

Cornips, L. M. E. A. (2012). Talen in Beweging. Maastricht University. https://doi.org/10.26481/spe.20120511lc

Document status and date:

Published: 11/05/2012

DOI:

10.26481/spe.20120511lc

Document Version:

Publisher's PDF, also known as Version of record

\section{Please check the document version of this publication:}

- A submitted manuscript is the version of the article upon submission and before peer-review. There can be important differences between the submitted version and the official published version of record.

People interested in the research are advised to contact the author for the final version of the publication, or visit the DOI to the publisher's website.

- The final author version and the galley proof are versions of the publication after peer review.

- The final published version features the final layout of the paper including the volume, issue and page numbers.

Link to publication

\footnotetext{
General rights rights.

- You may freely distribute the URL identifying the publication in the public portal. please follow below link for the End User Agreement:

www.umlib.nl/taverne-license

Take down policy

If you believe that this document breaches copyright please contact us at:

repository@maastrichtuniversity.nl

providing details and we will investigate your claim.
}

Copyright and moral rights for the publications made accessible in the public portal are retained by the authors and/or other copyright owners and it is a condition of accessing publications that users recognise and abide by the legal requirements associated with these

- Users may download and print one copy of any publication from the public portal for the purpose of private study or research.

- You may not further distribute the material or use it for any profit-making activity or commercial gain

If the publication is distributed under the terms of Article $25 \mathrm{fa}$ of the Dutch Copyright Act, indicated by the "Taverne" license above, 


\section{Talen in beweging}

\section{Rede}

uitgesproken bij de openbare aanvaarding van het ambt van

bijzonder hoogleraar Taalcultuur in Limburg aan de

Universiteit Maastricht bij de capaciteitsgroep Letteren en Kunst van de Faculteit Cultuur- en Maatschappijwetenschappen op

vrijdag I I mei 2012

door Leonie Cornips

Maastricht University provincie limburg 
Mijnheer de Rector Magnificus,

Lieve familie en vrienden,

Beste collega's, kennissen en geïnteresseerden

\section{Introductie}

Een fragment van Connie Palmen schetst hoe in haar herinnering een kind in Limburg in de tweede helft van de vorige eeuw tussen allerlei talen en dialecten opgroeide. Ik citeer:

'Het lage land van mij ligt ook zo gek, zo buitengaats, een verloren, bijkans afgeknepen slurf die overal in bungelt behalve in Nederland. Voor mijn tiende kende ik andere nationaliteiten beter dan de Nederlandse. Ingeklemd tussen tweetalige Belgen, Duitsers, andere Limburgers en dagelijks ondergedompeld in het Latijn van de kerk, was Nederlands de zoveelste taal, een die ik op school moest leren spreken. Wat ik als kind niet zag begreep ik later, dat ik omringd was door vreemde klanken, door het geroezemoes van het betoverende, onbegrijpelijke Latijn van mijn ochtenden, het Vlaams en Frans van het land aan de ene kant en het Duits van het land aan de andere kant, met de verschillende dorpsdialecten boven en onder me (...). Niks verstond ik en alles'. ${ }^{{ }}$

Palmen beschrijft Limburg als nauwelijks behorend tot Nederland door de aandacht te vestigen op de excentrische ligging van deze provincie, de onbekendheid met andere Nederlanders en het Nederlands.

In dit fragment introduceert zij diverse taalvariëteiten die aan specifieke plekken verbonden zijn. Het Nederlands hoort binnen de schoolmuren thuis, Latijn in de kerk en Vlaams, Frans en Duits aan de overkant van de zeer nabije grenzen, en dialecten binnen de grenzen van de dorpen. Bovendien behoren tot die specifieke talen en plekken, specifieke sprekers in specifieke rollen. Onderwijzers en leerlingen spreken Nederlands, de pastoor spreekt Latijn en familie, dorpsgenoten en mede-Limburgers dialect. Het Nederlands dat als tweede taal geleerd moet worden, is de enige uitzondering op de gepresenteerde hechte verbinding tussen één plek, één spreker en één taal. Deze hechte verbinding wil zeggen dat elke spreker dwingend als eentalig voorgesteld wordt vanaf zijn of haar geboorte. Daarnaast weerspiegelt elke spreker in hoe hij of zij spreekt onontkoombaar de plek waar hij of zij geboren en opgegroeid is. ${ }^{2}$

${ }^{\mathrm{I}}$ Palmen (I995: 49)

${ }^{2}$ Heller (20I I), Quist (2010) 
De hechte verbinding tussen één plek, één spreker en één taal leeft in de verbeelding van de meeste sprekers. Deze verbeelding is waarschijnlijk grotendeels gevoed door taalkundige en vooral dialectologische onderzoekspraktijken. De dialectologie baseert zich op de geografische visie waarin een 'plek' niet meer dan een coördinaat op een landkaart is. Een plek verschilt van een andere plek doordat ze relationeel in de ruimte gesitueerd zijn en verschillende fysieke karakteristieken hebben. ${ }^{3}$ Een 'plek' wordt dus voorgesteld als een objectief gegeven en niet als 'keuze'.

\section{Een isoglossenkaart}

Een casus van een dialectologische uitwerking van deze relationele visie op 'plek', zijn de zogenaamde isoglossenkaarten die voor diverse talen en dialecten in de wereld geproduceerd zijn. Een isoglossenkaart van Limburg visualiseert het territoriale gebied van de provincie als een dialectlandschap dat traditioneel in zes dialectgroepen onderverdeeld is. ${ }^{4}$

De isoglossen bakenen deze dialectgroepen af op basis van klankverschijnselen in woorden. ${ }^{5}$ Maar deze kaart doet de complexe relatie tussen (groepen) mensen en datgene dat zij spreken tekort. De kaart suggereert dat er inderdaad zoiets als taalgrenzen bestaan die, net als politieke grenzen, mensen en hun dialecten haarscherp van elkaar scheiden. Bovendien suggereert een dergelijke kaart dat mensen uitsluitend eentalig zijn en altijd op dezelfde wijze spreken. ${ }^{6}$

\section{Afbakening dialect is arbitrair}

Ondertussen laat taalkundig onderzoek zien dat iedere afbakening van een dialect arbitrair is. Elk talig verschijnsel kan, afhankelijk van de grammaticale component, dus woordenschat (lexicon), uitspraak (fonologie) en zinsbouw (morfosyntaxis), een verschillende geografische distributie vertonen. Doordat die componenten elkaar niet overlappen, vloeien - wat wij talen en dialecten noemen - in een geografisch gebied als waaiers in variërende breedtes in elkaar over. Het is dus niet mogelijk om taalkundig vast te stellen waar het ene dialect begint en het andere ophoudt. Daardoor is het ook niet mogelijk om taalkundig een 'taal' of een 'dialect' te definiëren indien deze termen aan typologisch nauw verwante variëteiten refereren zoals aan het Nederlands, Duits, Fries of een Limburgs dialect. ${ }^{7}$ Het

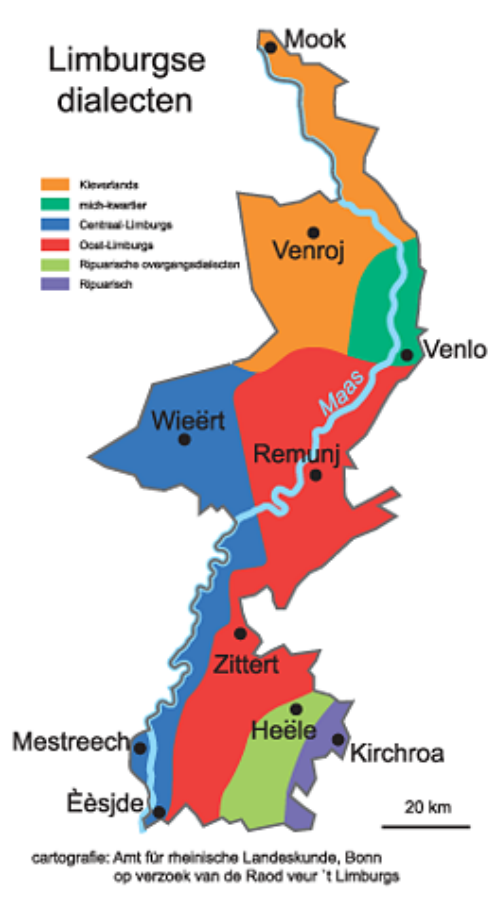

Kaart I:

Isoglossenkaart van Limburg

3 Johnstone (2004, 2010)

${ }_{4}$ Zie http://www.limburgsedialecten.nl/upload/s 76/Com_o9kaart-Limburgs-dialect_groot. png (geraadpleegd I I mei 20I2) 5 Goossens \& Van Keymeulen (2006), Hermans (to appear) ${ }^{6} \mathrm{Zie}$ voor het tegendeel Cornips (2OI2)

7 Zie voor discussie Leerssen (I 999), Cornips, Jaspers \& De Rooij (to appear) 
verschil tussen wat als een 'taal' en 'dialect' beleefd wordt, is afhankelijk van de taalideologie in een samenleving en het gevolg van politieke beslissingen. ${ }^{8}$ Daarnaast is er geen enkel talig verschijnsel in de dialecten van Nederlands Limburg dat zich volledig over die provincie uitstrekt of zich tot die provincie beperkt. ${ }^{9}$

\section{De onzichtbaarheid van talen in beweging in taalkundig onderzoek}

Een isoglossenkaart is het resultaat van historisch dialectologisch onderzoek. Met een isoglossenkaart probeerde de dialectoloog verschillen tussen dialecten, te verklaren als gevolg van uiteenlopende historische ontwikkelingen. Historisch onderzoek selecteerde daartoe bij voorkeur sprekers als respondenten die in een dorp of agrarische plek geboren en getogen zijn. Dit zijn de sprekers die het 'dialect' spreken dat zij via hun ouders verworven hebben die ook tot die plek door geboorte behoren. Deze respondenten zijn vaak oudere mannen die niet uit het dorp weg zijn geweest. ${ }^{\text {10 }}$ Net als in de historische en moderne dialectologie, focust ook het theoretisch onderzoek naar microvariatie op deze respondenten. Dit type onderzoek probeert de grenzen van taalvariatie te beschrijven en te verklaren.

De relevante vraag is waarom bepaalde zinnen of taalstructuren als bijvoorbeeld in (I) niet voorkomen terwijl ze logisch wel mogelijk zijn. Een zin als in (I) waarin het bepaald lidwoord $d e$ achter het zelfstandig naamwoord man staat is niet mogelijk in het Nederlands of in een dialect in het Nederlandse taalgebied maar wel bijvoorbeeld in het Deens:

\section{(I) Ik zie man de niet}

Het onderzoek naar microvariatie probeert mogelijke en onmogelijke zinnen tussen zeer nauw verwante taalvariëteiten zoals dialecten te achterhalen. ${ }^{\text {II }}$

Het geschetste taalkundig onderzoek versterkt echter door de focus op een bepaald type respondent een theoretische ideologie waarin de ideale spreker verankerd is aan één plek en bovendien uitsluitend dialecttalig is. Tegelijkertijd ontstaat er de indruk dat oudere en vaak mannelijke sprekers de kernleden van een gemeenschap zijn. ${ }^{12}$ Ten slotte informeren reconstructies van oudere taalfases dit type onderzoek. ${ }^{13}$ De focus op respondenten die geboren en gebleven zijn in dezelfde plek, is evenzeer te vinden in het klassieke sociolinguïstisch onderzoek van Labov. In dit type onderzoek bestuderen taalkundigen hoe taalvariatie tussen groepen sprekers in steden samenhangt met sociale verschillen tussen die sprekers. ${ }^{14}$ In dialectgeografisch en Laboviaans sociolinguïstisch onderzoek in Nederland blijft dus studie naar hoe vrouwen spreken evenals jongeren, meertaligen en
${ }^{8}$ Haugen (r 997[ [966]), Milroy (200I)

9 Barbiers e.a. (2005, 2008); De Schutter e.a. (2005), Goeman e.a. (2008), Notten (I988: 57), Cornips (to appear).

ro De zogenaamde NORM (nonmobile, older, rural, male)- spreker, zie Chambers \& Trudgill (I998:29)

I Zie bijvoorbeeld Barbiers, Cornips \& van der Kleij (2002), Cornips \& Corrigan (2005a).

${ }^{12}$ Eckert (2OI I)

13 Van Bree (i 996: 235)

${ }^{14}$ Labov (I994), zie voor Limburg Cornips (I 994) \& Hinskens (I993) 
mensen die mobiel zijn of waren, onderbelicht. Het gevolg is dat de illusie van een hechte verbinding tussen één spreker, één taal en één plek kan voortduren.

\section{Taalvariatie}

De relatie tussen spreker, plek en taal is echter veel meer complex, fluïde, meerdimensionaal en ambigu dan het taalkundig onderzoek voorstelt. Ik laat $\mathrm{u}$ nu drie geluidsfragmenten horen die ieder op zeer verschillende talige wijze een plek als Heerlen vormgeven:

\section{Geluidsfragment $\mathrm{I}^{\mathrm{IS}}$}

Het eerste geluidsfragment dateert van begin jaren negentig. De sprekers zijn oudere heren die in Heerlen geboren en getogen zijn. Zij vertellen over vroeger toen de blaas van een geslacht varken als voetbal gebruikt werd. Het dialectologisch onderzoek baseert zich op datgene dat deze respondenten spreken.

\section{Geluidsfragment $2^{16}$}

Het tweede geluidsfragment dateert ook van begin jaren negentig. We luisteren hier naar een jongere man die ook in Heerlen geboren en getogen is. Hij vertelt dat de wijkagent vroeger iedereen in de buurt kende en bij je ouders thuis langs ging als je iets op je kerfstok had. Het sociolinguïstisch onderzoek baseert zich op datgene dat deze respondent spreekt.

\section{Geluidsfragment $3^{17}$}

Het derde fragment is recent opgenomen. We luisteren hier naar een oudere man opgegroeid in Tuinwijk in Eisden, Maasmechelen in België. Hij spreekt in dit fragment zoals hij het zelf noemt Cité-Duits; een eigen benaming voor een variëteit die hij als klein kind onderling met anderen en vroeger als mijnwerker gesproken heeft. Datgene dat hij spreekt, zal sterk lijken op dat wat vroeger ondergronds in de Oranje Nassau mijnen van de Oostelijke Mijnstreek gesproken werd. Deze spreker vertelt dat hij de functie van opzichter in de mijn aangeboden kreeg. Er vindt geen onderzoek plaats op datgene dat deze respondent spreekt.

\section{Vrijwillige regio's}

De talige verschillen tussen de sprekers uit de drie fragmenten in één plek of regio die we gehoord hebben, ondersteunen de theoretische ontwikkelingen binnen de 


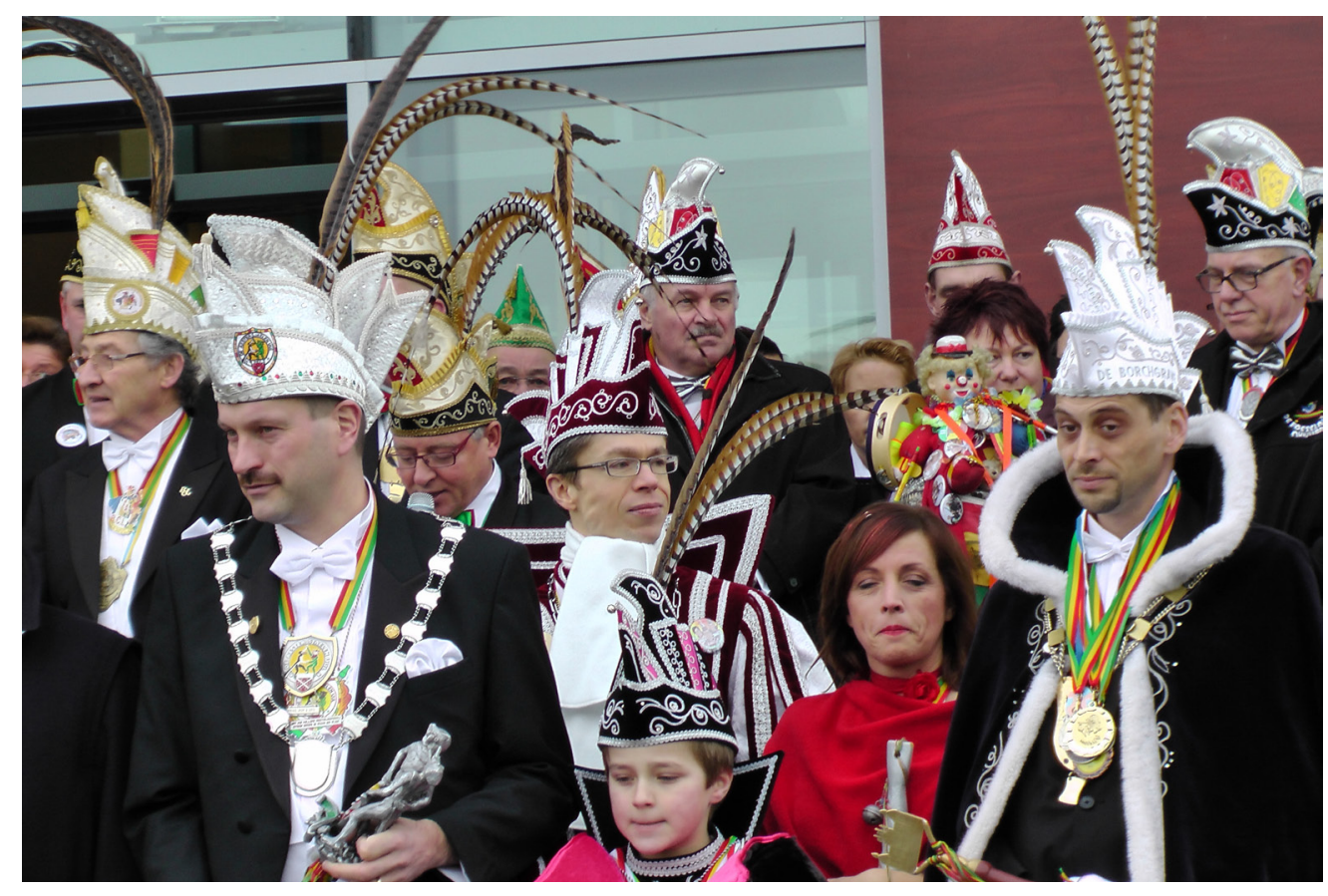

sociale geografie in de tweede helft van de twintigste eeuw. Hierin is het idee van de 'traditionele regio' vervangen door dat van de 'vrijwillige regio'. In dit perspectief is een 'plek' het resultaat van de diverse keuzes die verschillende groepen mensen maken hoe zij de wereld zoals zij die beleven indelen. Mensen creëren een fysieke ruimte tot een 'plek' als betekenisvolle context van menselijke handelen. Zij identificeren zich met een plek zodanig dat het voor hen betekenis heeft, vertrouwd is en transparant in vergelijking met een 'plek' elders. ${ }^{8}{ }^{8}$ Vanuit deze context impliceert een plek creëren dat groepen mensen op een bepaalde wijze spreken, dat zij op een bepaalde wijze aan gebeurtenissen deelnemen en rituelen uitvoeren.

Op deze wijze zijn ze ook herkenbaar voor anderen die hen daardoor als van één en dezelfde plek identificeren. Vooral in publieke gebeurtenissen krijgt de onderlinge verbondenheid tussen mensen door hoe zij spreken, waarover zij spreken en hoe zij zich gedragen vorm en uitdrukking. En hierin onderscheiden zij zich tegelijkertijd van anderen. ${ }^{19}$ In de publieke ruimte is zicht- en hoorbaar wie kan spreken en wie niet en welke talen en talige elementen gehoord mogen worden en welke niet. ${ }^{20}$ Taalcultuur speelt zich dan ook af in sociale gebeurtenissen in de publieke ruimte, de 'plek' waar het gevoel van ergens 'bij te horen' ontstaat en waar groepsidentiteiten gecreëerd worden. ${ }^{21}$ Deze identificaties vinden plaats in een voortdurend proces van het met elkaar uitwisselen van ideeën, gevoelens en
Wachten op de Heerlense "Blauwe Schuit" in Echt (14 Februari 201 2, foto Cornips)

${ }^{18}$ Johnstone (2004, 2010, 20 I Ia,b), Gal (20I I)

19 Brubaker \& Cooper (2000)

${ }^{20}$ Bucholtz \& Hall (2005, 2008), Cornips \& De Rooij (to appear) ${ }^{21}$ Cornips, De Rooij \& Stengs (te versch), Eckert (2OIO) 
meningen. ${ }^{22}$ Groepsidentificaties veranderen continu afhankelijk van de politieke en sociaal-culturele context. Groepen en relaties tussen groepen zijn daarmee niet statisch, niet eendimensionaal en niet voorspelbaar. Mensen behoren niet tot één groep maar tot vele omdat regionale, sociale en etnische identiteiten in een veld van tegenstellingen interageren. Waar men in Limburg als overal elders in Europa in die publieke ruimte voor een dialect kiest, is lokale identiteitsvorming zeer waarschijnlijk van emotionele betekenis.

\section{Taalcultuur}

Onderzoek naar taalcultuur, dat de opdracht is van deze leerstoel, zal dan ook proberen inzicht te krijgen in het hele talige feit dat essentieel is voor sociale, etnische en regionale identificaties en de veranderingen hierin. ${ }^{23}$ Het hele talige feit verwijst naar de dubbelrol van 'taal' als cultureel bindmiddel: taal is voor mensen een middel om cultuur te produceren en te reproduceren maar taal vormt zelf ook het hart van een cultuur. Als groepsidentificaties veranderen, veranderen culturen en talen en in die veranderingen construeren groepen zich weer. Taalcultuur refereert aan het hele talige feit dat de onontkoombare hechte vervlechting weergeeft tussen de talige vorm, de context van de talige vorm en de taalideologie.

De taalkundige die de grenzen van taalvariatie onderzoekt, focust op de talige vorm of structuur door deze uit zijn context te lichten. Het is een uitdaging voor deze taalkundige om het hele scala aan taalverschijnselen dat een spreker in al zijn interacties en identificaties kan inzetten, theoretisch te verklaren. Immers, tot de betekenis van de taalvorm draagt de actuele context bij waarin de vorm gebruikt wordt. Afhankelijk van hoe mensen zich tot die context verhouden, verbinden zij bepaalde talige vormen met ideeën over de sprekers ervan. ${ }^{24} \mathrm{Op}$ deze wijze vindt een transformatie plaats van talige kenmerken in sociale beelden waarbij talige verschillen, sociale contrasten aanduiden. ${ }^{25}$ Sprekers geven aan hun talige productie een extra symbolische betekenis en dit kan leiden tot taalvariatie en taalverandering. Voor de sociale wetenschapper is het vanzelfsprekend dat de talige keuzes de sprekers juist maken tot wie ze zijn en tot welke groepen ze willen behoren en hoe ze een plek eigen maken. Of meer precies uitgedrukt, voor de sociale wetenschapper is het vanzelfsprekend dat deze keuzes sprekers toestaan om zichzelf in identificaties telkens opnieuw vorm te geven. ${ }^{26}$ Voor de sociale wetenschapper, echter, is het een uitdaging om te kunnen achterhalen waarom in identificaties niet alle logisch mogelijke talige verschijnselen ingezet kunnen worden zoals blijkt uit de onmogelijke zin in (I). Welke aard hebben deze talige restricties en hoe en in welke context kunnen sprekers deze restricties opheffen?
${ }^{22}$ Cornips \& Stengs (2010)

${ }_{23}$ total linguistic fact, zie Silverstein (1985), zie ook Hymes (I974)

${ }^{24}$ Kroskrity (2000), Irvine (200I)

${ }_{25}$ Preston (2002)

${ }^{26}$ Joseph (2010:9) 
De talige vorm, het taalgebruik en de taalideologie beïnvloeden elkaar voortdurend. Het talig materiaal dat we produceren, heeft immers altijd een bepaalde gebruiksgeschiedenis en is daarom meerstemmig. ${ }^{27}$ Eén talige vorm kan verschillende gebruikscontexten oproepen, en kan tegelijkertijd verschillende betekenissen of ladingen hebben voor verschillende taalgebruikers. Zo kan een spreker met een zachte ' $\mathrm{g}$ ' regionaal geduid worden als iemand van beneden de grote rivieren, religieus als Katholiek, sociaal-cultureel als 'gastvrij' of als het 'meest sexy' zoals recentelijk bleek uit een enquête van datingsite Parship. ${ }^{28}$

\section{Praten met een zachte 'G' het sexiest}

ARTIKEL

REACTIES

Door: redactie

24-11-11 - 12:35

\begin{abstract}
Beweerd wordt dat de taal van de liefde universeel is, maar een Brabants accent klinkt ligt toch net iets lekkerder in het gehoor ligt dan plat Achterhoeks. Een poll van datingsite Parship wijst uit dat we het spreken met een zachte 'G' het meest opwindend vinden.
\end{abstract}

Parshipleden werd gevraagd of ze een voorkeur hebben voor een accent van een toekomstige partner. Oftewel, welk dialect vind je het meest sexy?

Gekozen kon worden uit negen mogelijkheden: Brabants, Zeeuws, Zuid-Hollands/Rotterdams/Haags, Gronings/Drents, NoordHollands/Amsterdams, Limburgs, Fries, Twents/Achterhoeks en Utrechts.

Zowel veertig procent van de single mannen als vrouwen kozen voor Brabants. Het Limburgs en Hollands/Amsterdams kwamen op de tweede en derde plek. Bij single mannen hoef je niet aan te komen met een Utrechts accent. Dat eindigde als laatste. En bij de single vrouwen valt een Zeeuws accent niet in de smaak.

\section{Onvervreemdbaar bezitsconstructie}

Vragen die in interdisciplinair onderzoek naar taalcultuur dan ook centraal staan, zijn hoe mensen zich identificeren met anderen en met wie tegelijkertijd niet en welke talige elementen in deze processen ingezet worden en welke niet? Een goed voorbeeld hoe onderzoek naar taalcultuur inzicht kan bieden in sociale, en regionale identificaties en de veranderingen hierin is het volgende. ${ }^{29}$ Uit onderzoek van

Party houdt vol:
Illustratie I: Datingsite Parship

\section{MEER OVER YOI}

\section{NIEUW \\ 23:10 Kampioen Celt \\ 23:05 'Tori Spelling g \\ 22:53 Chinese blinde \\ 22:52 Drew Barrymo \\ 22:31 'Samenwerking herhaling vatba}

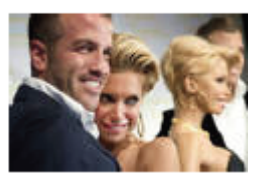
'Sylvie en Rafael al maand uit elkaar'
TOP VANDAAG TOP DI

\footnotetext{
${ }^{27} \mathrm{Zie}$ voor hier en onderstaande tekst Cornips, De Rooij \& Stengs (20I I), Jaspers (2005: 27-30) voor de Nederlandstalige context.

${ }^{28}$ Zie http://www.telegraaf. $\mathrm{nl} /$ vrouw/psyche_relatie/ı roor 739/_Het_Brabants_ het_sexiest_.html (geraadpleegd I I mei 2OI 2)

${ }^{29}$ Zie Cornips, De Rooij \& Stengs (te versch.)
} 
Pierre Bakkes begin jaren negentig blijkt dat jongeren in het dialect van Montfort, in tegenstelling tot ouderen, nog nauwelijks zinnen zeggen als 'Hij wast $z i c h$ de handen'. ${ }^{\circ}$

Dit type zin - een onvervreemdbare bezitsconstructie genoemd - is verspreid over veel dialecten in het oosten van Nederland. Een constructie als 'Hij wast zich de handen' behoort in Nederland tot een dialect maar de letterlijke Franse vertaling, namelijk "Il se lave les mains" tot de officiële standaardtaal in Frankrijk.

Bakkes schaart deze teruggang in gebruik onder de noemer 'dialectverlies', dat wil zeggen dat dit type zin uit het dialect verdwijnt. Maar, het onderzoek van mijzelf, ook begin jaren negentig, toont aan dat juist de jongeren in Heerlen de onvervreemdbare bezitsconstructie significant meer gebruiken in hun NEDERLANDS dan de oudere sprekers. ${ }^{32}$ Een type zin dat karakteristiek is voor de oostelijke Nederlandse dialecten verdwijnt dus uit het dialect van de jongere sprekers uit een Limburgs dorp maar wint terrein in het gesproken Nederlands van jongere sprekers 50 kilometer meer naar het zuiden. Of anders gezegd, het Nederlandse 'hij wast $z i j n$ handen' dringt door in het dialect van Montfort maar verdwijnt uit het Nederlands van Heerlen voor het dialectische 'Hij wast zich de handen'. ${ }^{33}$ Deze tegen-

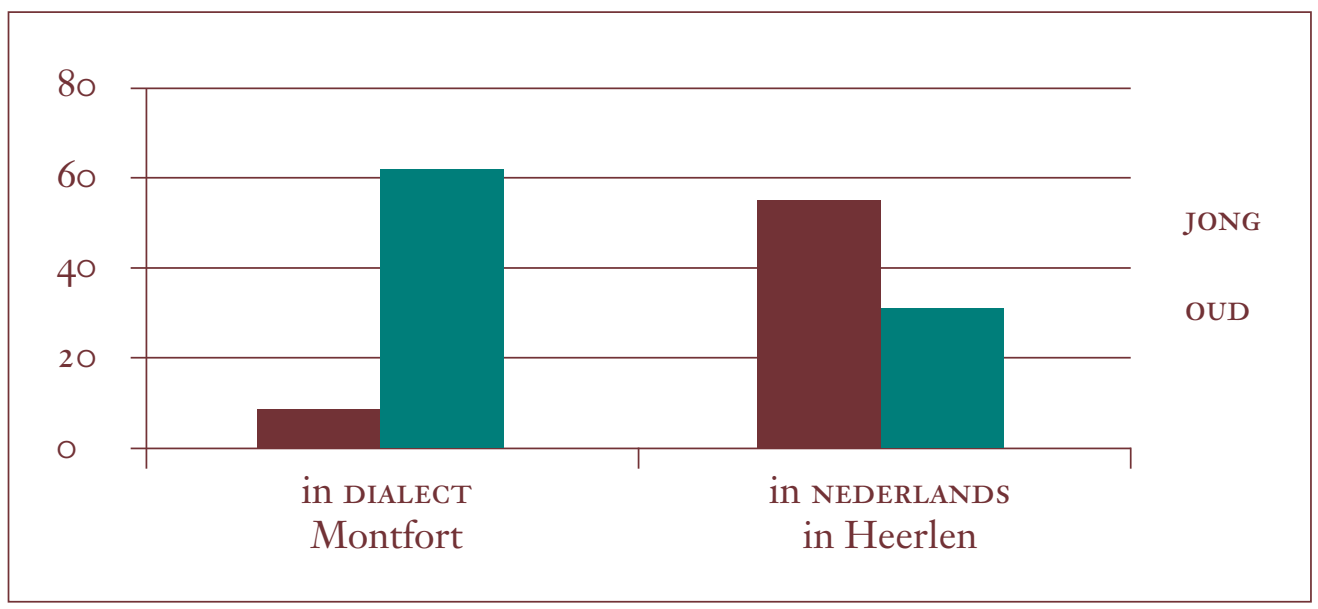

Zich/ SIG (51)

zich zijn/ SIG his (23)

$\triangle \mathrm{Hem} / \mathrm{him}(3)$

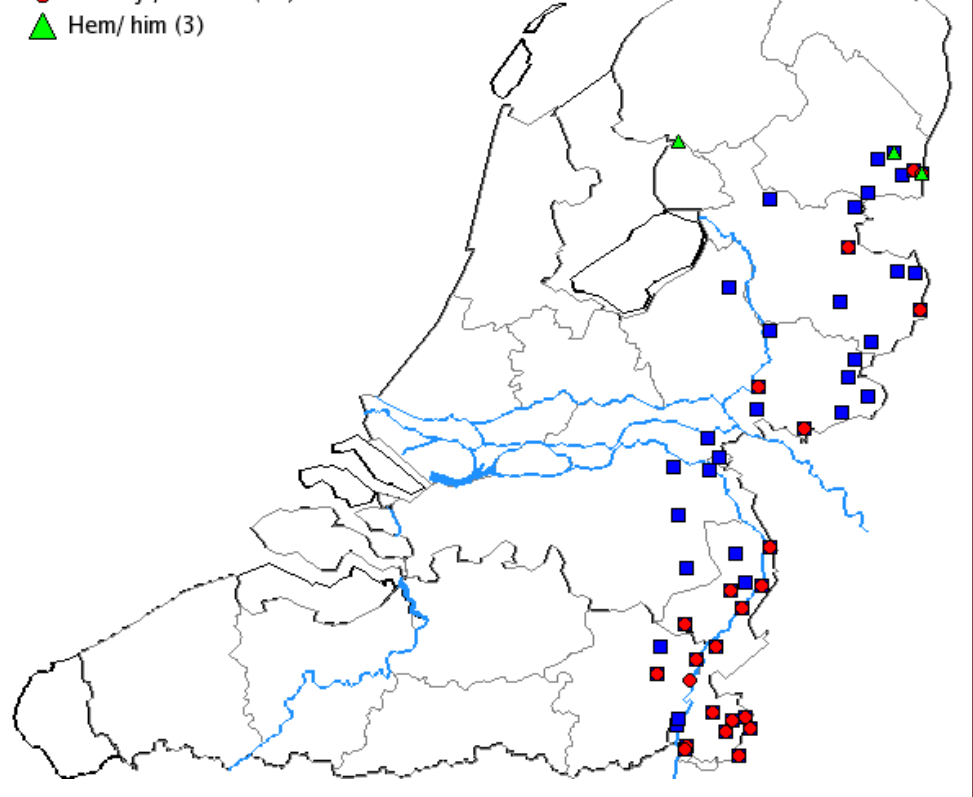

Kaart 2: Verspreidingsgebied onvervreemdbaar bezitsconstructie als "bij wast zich de banden" ${ }^{1}$

Figuur I: 'Hij wast zich de banden' in percentages ${ }^{34}$

\footnotetext{
$3^{\circ}$ Bakkes (1996)

${ }^{31}$ Zie voor deze kaart Barbiers e.a. (2005)

${ }^{32}$ Cornips (1994, 2003/201 2)

${ }_{33}$ Cornips (2006)

34 Zie voor de kwantitatieve analyse, Cornips (to appear)
} 
gestelde veranderingen kunnen niet geduid worden in taalgeografisch en Laboviaans sociolinguïstisch onderzoek waarin hoe iemand spreekt of hoe iemands grammatica eruitziet, iemands geboorteplek en sociale positie reflecteert. ${ }^{35}$ We hebben daarvoor kennis nodig over de symbolische betekenis van de talige vorm die, afhankelijk van wie deze produceert en interpreteert, een potentiële aanwijzing (index) is voor een 'plek', sociale positie of stereotypering. De variant 'Hij wast zich de handen' kan 'een couleur locale' of solidariteit indexeren in het Heerlens Nederlands, gesproken in een stad die in de tijd van het onderzoek als Hollands gezien en beleefd werd maar als iets van 'vroeger' of 'plattelands' in Montfort. Deze kennis is te achterhalen als het interdisciplinair onderzoek naast de talige vorm, ook de context en de taalideologie in samenhang bestudeert. Dit vereist een herzien van gevestigde concepten en methoden van onderzoek waardoor de sterke kanten van zowel taalkundig, sociolinguïstisch als antropologisch onderzoek elkaar kunnen aanvullen en versterken. ${ }^{36}$

\section{Constructie van Limburgse identiteit}

Limburg is zo'n unieke casus om taal als bindmiddel voor de processen van regionale, sociale en etnische identificaties te onderzoeken omdat Limburg een meertalig krachtenveld is waar naast Nederlands en dialect ook Engels, Duits, Frans, Italiaans, Moluks/Maleis, Spaans, Arabisch, Turks, Servisch, Kroatisch, Bosnisch, Berber, Roemeens, Dari, Pools en Papiaments gesproken wordt. ${ }^{37}$ Bovendien heeft het dialect een grote vitaliteit. Recent claimen ongeveer zo'n 900.000 mensen of $75 \%$ van de bevolking in Limburg een Limburgs dialect te spreken. ${ }^{3}$

Bovendien is identificatie met Limburg pas vrij recent mogelijk en staan daartoe vele talige bronnen ter beschikking. De territoriale grenzen van de huidige provincie zijn ontstaan tussen 18 I 5 en $1839 .{ }^{39}$ Voor I 8 I 5 bestond de naam Limburg nog niet voor dit gebied en voor I 839 bestond de provincie Limburg nog niet in de huidige afbakening. Dit weerlegt haarscherp het idee dat zoiets als een Limburgse identiteit al vanaf oudsher bestaan heeft. In de negentiende eeuw identificeerde men zich bovendien niet met Limburg maar wel met eigen dorp of stad..$^{\mathrm{I}}$
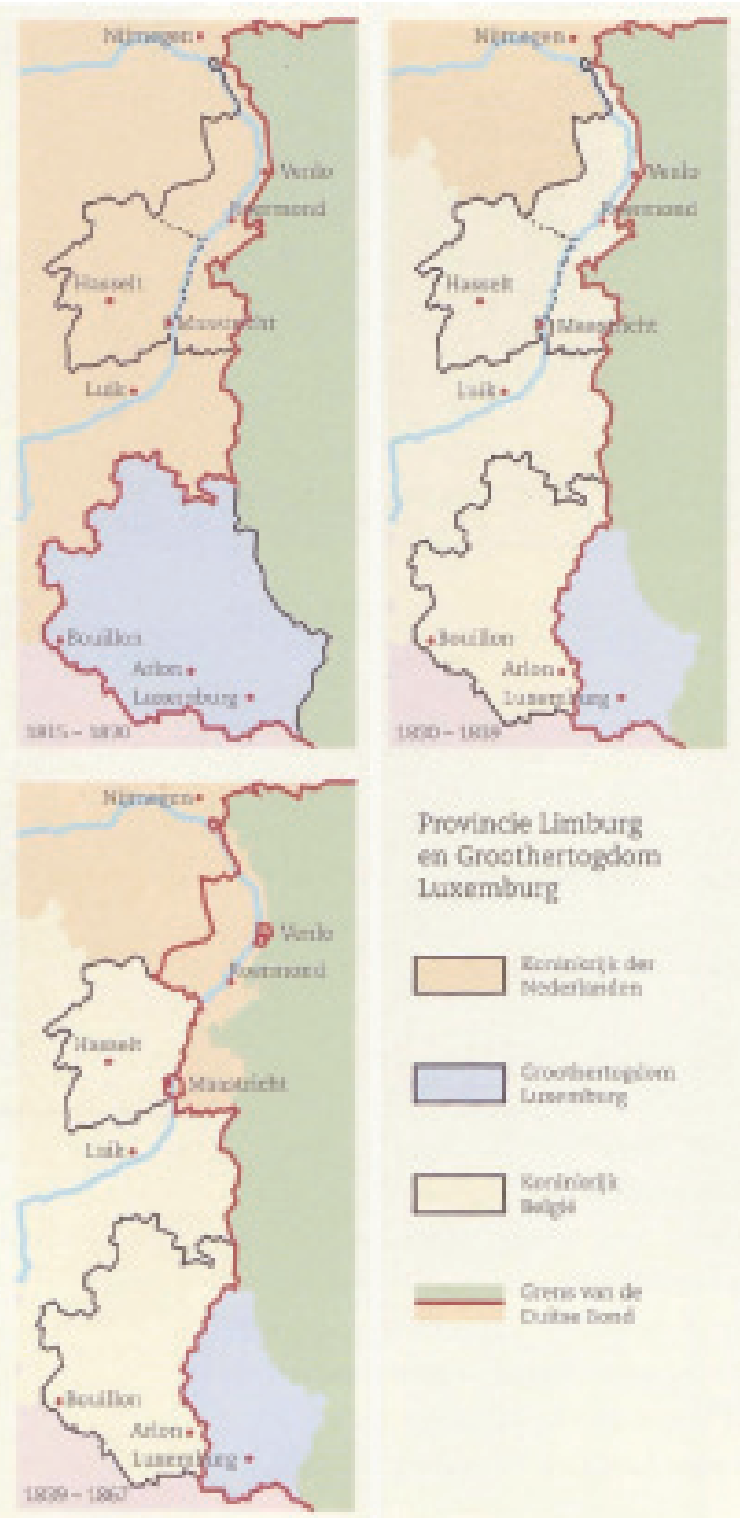

Provincie Limbarg en Groethertogedom uxemburg
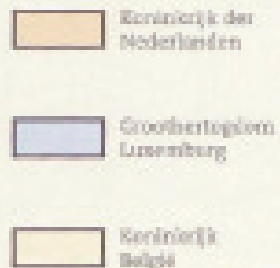

Cores vand buitse Sond
Kaart 3: Limburg in verhouding tot de Duitse Bond I 839-г867. Uitzondering: vestingen van Maastricht en Venlo ${ }^{4}$ 
De inwoners van de nieuwe provincie konden zich uiteindelijk als Limburger identificeren omdat zij in het proces van Limburger-worden ook tegelijkertijd Nederlander-werden. ${ }^{42}$ Ad Knotter spreekt dan ook over een proces van negatieve integratie. Identificaties als 'Limburger' werden mogelijk in oppositie met 'de Hollander'. In die tegenstelling kon men culturele praktijken, waardoor men zich als verschillend van de 'Hollander' beleefde, als eigen en uniek bestempelen en zich zo tegelijkertijd van de Hollander distantiëren. Thijs Wöltgens verwoordde zijn beleving over deze tegenstelling waarin hij de Limburger als zeer passief voorstelt als volgt:43

'(Toch is) het idee van 'Limburgers' [is] een constructie achteraf. Anderen hebben ons tot Limburgers gemaakt. Die anderen zijn allereerst de 'Hollanders'. Zij hebben onze identiteit gecreëerd. Wij waren wingewest, zij de republiek. Wij waren Katholiek, zij Calvinistisch. Wij waren onderdanen, zij hadden de macht. En na de ontwikkeling van de mijnindustrie: wij waren ondergronds en zij commandeerden vanuit veilige kantoren. Deze tegenstellingen, het verzet tegen de Hollanders, heeft het verschijnsel Limburger opgeleverd.'

Uit deze passage blijkt ook hoe in de beleving van Wöltgens de tegenstelling tussen Holland en Limburg aanwezig blijft maar telkens door de tijd heen nieuwe vormen en uitdrukkingen krijgt. Kijkend naar de historische context in de vroege negentiende eeuw, dan is taal wel zeer waarschijnlijk een attribuut geweest in de geconstrueerde tegenstelling tussen Limburg en Holland. Na toetreding tot het Koninkrijk in I8 5 kreeg het nieuwe gebied Limburg te maken met het besluit van koning Willem I die het Nederlands als officiële taal in geheel Limburg voorschreef. Ambtenaren die vanaf I januari i 823 niet over voldoende kennis van het Nederlands beschikten, moesten naar de Waalse en/of Duitse gebieden overgeplaatst worden. Hennequi, de burgemeester van Maastricht die in die tijd uitsluitend het Frans beheerste, schreef koning Willem I dat hij afstand deed van zijn functie. Het Nederlands was in Limburg onbekend daar iedereen het lokale dialect sprak en de bovenlaag in meer formele domeinen het Frans en/of Hoogduits gebruikte al naar gelang waar men woonde. ${ }^{44}$ Het kan niet anders dan dat het Nederlands met Holland en het dialect met de lokale gemeenschap geassocieerd werd.

\section{Stereotypering}

Vaak is stereotypering en in het slechtste geval vooroordelen de grondslag van groepsidentiteiten. ${ }^{45}$ En in dit proces kunnen taal- en cultuurelementen gepoliti-

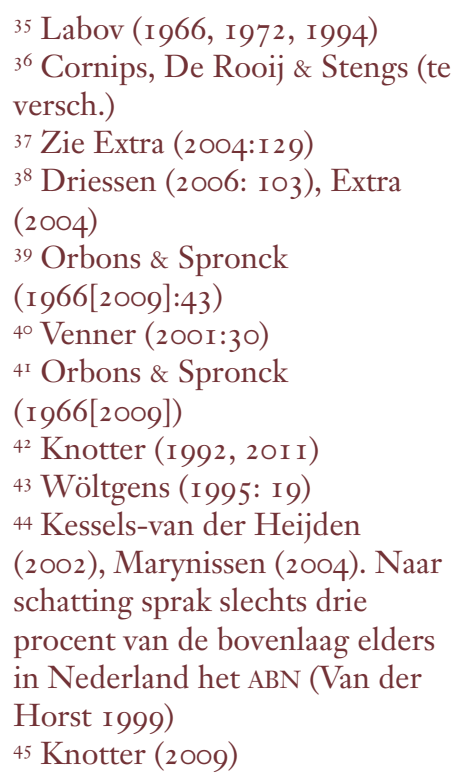


seerd worden. Wilders deed dit bij zijn presentatie van de kandidatenlijst van de PVV van de provinciale Staten in 2010 met de leus 'geen halal, maar zuurvlees! Geen moskee, maar carnaval! Geen preken van haatimams, maar buutreedners!' 46 Hij doelde hier op een Limburgse identiteit maar een dergelijke identiteit is geen etiket dat 'iemand' op basis van waargenomen gemeenschappelijke cultuurelementen zoals dialect, zuurvlees en carnaval aan een groep van buitenaf kan toeschrijven. Het is de groep zelf die de cultuurelementen als kenmerkend en afbakenend voor het saamhorigheidgevoel in de provincie moet herkennen en beleven. ${ }^{47}$ Bovendien is elke oppositie weer ingebed in een ruimere oppositie. Iemand voelt zich van een bepaalde wijk of straat in Venlo, maar ook van Noord-Limburg, Limburg, van Nederland, Europa en zo verder. Bovendien interageren regionale met sociale en etnische identificaties.

Vanuit die inbedding is de Limburgse identiteit niet eenduidig. Er bestaat in de beleving van de inwoners verschillen binnen een dorp of stad, als wel tussen de diverse dorpen en steden, en er bestaat vooral een noorden en een zuiden van de provincie. ${ }^{8}$ Limburg is zo uniek omdat al die verschillen talig worden beleefd. De 'zachte' en 'langgerekte' klanken van de Zuid-Limburger verwijzen via een complex proces van betekenisgeving naar de op de vruchtbare löss gemoedelijke levende Zuid-Limburger terwijl de 'harde' uitspraak van medeklinkers naar de hardwerkende Noord-Limburger op de kale zandgronden verwijzen. In deze processen zijn verschillen tussen dialecten nooit waardevrij en nooit zonder sociale betekenis.

\section{Gevolgen van globalisering}

Limburg, Nederland en gebieden elders in de wereld zijn de laatste twee decennia ingrijpend en zichtbaar veranderd door het proces van globalisering. Globalisering is natuurlijk niet nieuw, dat blijkt bijvoorbeeld wel uit de geschiedenis van de voormalige Oostelijke Mijnstreek maar nieuw is wel de intensiteit, schaal, grootte en onvoorspelbaarheid van culturele en talige ontmoetingen die nu overal plaatsvinden met grote gevolgen voor processen van identiteitsvorming. ${ }^{49}$ In een tijd waarin een moderne samenleving mobiliteit impliceert, ${ }^{50}$ is taal geen geïsoleerd fenomeen.$^{5}$

In de dominante nationale context wordt Limburg gezien en beleefd als de periferie van Nederland en Limburg is dan ook een goede casus voor een regio als zovele in Europa waarin de laatste decennia minderheidstalen van belang zijn in het steeds meer nadrukkelijk vormgeven van regionale identiteiten zoals het Bretons in Frankrijk, het Welsh in Groot-Brittannië, het Corsicaans in Frankrijk of het Catalaans in Spanje..$^{2}$
${ }^{6}$ Zie: http://pvv.nl/index.php/ component/content/article/36geert-wilders/3777-speechgeert-wilders-presentatiekandidatenlijst-ps-limburg.html (geraadpleegd I I mei 20I2)

47 Wijers (2009: I 32 )

${ }^{4}$ Knotter (2009), Wijers (2009)

49 Blommaert (20 I0), Jacquemet (2005), Van de Beek \& Gageldonk (2012)

$5^{\circ}$ Duyvendak (20I I)

${ }^{51} \mathrm{Zie}$ Structuurschets leerstoel (2010)

$5^{2}$ Extra \& Gorter (200I: IO) 
De hernieuwde aandacht voor het regionale hoeft geen nostalgisch of wanhopig antwoord te zijn op de geografische mobiliteit, de toegenomen heterogeniteit van de lokale demografie en economische wijzingen die globalisatie met zich meebrengt. De aandacht voor het regionale is het onvermijdelijke resultaat van het proces van globalisatie. ${ }^{53}$ In dit proces gaan dialecten steeds meer op elkaar en meer op de overkoepelende standaardtaal lijken. ${ }^{54}$ Er ontstaat een taalcontinuüm waarin dialecten en het Nederlands elkaar ingrijpend beïnvloeden. ${ }^{55}$ Maar, in dit talig naar elkaar toegroeien, vindt ook het tegengestelde plaats. Sprekers vergroten talige kenmerken uit die zij als eigen voor hun 'plek' beschouwen en cultiveren deze. Van dit laatste zou een zin als 'Hij wast zich de handen' in het Nederlands van Heerlen een voorbeeld kunnen zijn.

Globalisering is een algemeen proces dat de condities aanreikt die zowel tot dialectvervlakking leidt als tot een verhoogd bewustzijn van dialectverschillen die overblijven. Mensen spreken en schrijven meer over lokale verschillen dan voorheen en in dat praten en schrijven over lokale verschillen construeren groepen zich weer. ${ }^{56}$ De laatste decennia is het dialect in Limburg als elders in Europa steeds meer zichtbaar bijvoorbeeld in de comodificatie ervan zodat dialecten deel gaan uitmaken van de wijze waarop een locatie zich aan zijn inwoners en anderen als 'authentiek', 'echt' en 'uniek' presenteert. ${ }^{57}$ Dialectstereotyperingen helpen vaak om een bepaalde locatie symbolisch rijk te maken voor het 'doen van lokale of regionale identiteit'.

\section{Traditioneel versus nieuw taalgebruik}

De traditionele media als lokale dagbladen, televisie en radio vertolken meer het dominante nostalgische perspectief op dialecten als kwetsbaar cultureel erfgoed, als dragers van orale tradities en als markeerders van traditionele lokale identiteiten. ${ }^{59}$ De talige praktijken in dit domein zijn er vooral op gericht om het dialect dat als 'authentiek' en 'zuiver' ervaren wordt, te behouden door codificatie. Het is hier dat men ijvert voor woordenboeken, grammatica's, dictees en een uniforme spelling van het dialect. ${ }^{6}$ Tegelijkertijd bieden nieuwe elektronische media aan gebruikers tal van nieuwe vormen van sociale interactie en culturele en talige productie en consumptie. Dit domein is een 'plek' waar jongeren aan een lokale

Illustratie 2: Heerlens Nederlands $5^{8}$

${ }^{53}$ Johnstone (2004, 2010, 201 I)

${ }_{54}$ Auer e.a, (2005), Cornips \&

Corrigan $(2005 \mathrm{~b})$

${ }_{55}^{5}$ Giesbers (1989)

${ }^{56}$ Johnstone (2010), Gal \& Irvine (1995)

57 Androutsopoulos (20I I:74I)

${ }^{8} \mathrm{Zie}$ http://www.limburger. nl/article/20IO091 $7 /$ REGIONIEUWSo5/100919662/1006 (geraadpleegd I I mei 20I2) 59 Cornips, Leerssen, De Rooij \& Stengs (2009), Eckert (2008)

${ }^{60} \mathrm{http}: / / \mathrm{www}$.limburgsedialecten. nl/upload/s $76 /$ Spelling $\% 202003$. pdf 
traditionele basis kunnen ontsnappen en hun dialect in nieuwe betekenisvolle manieren kunnen vormgeven. ${ }^{6 \mathrm{I}}$ In het proces van globalisatie komen naast het dialect ook Engels en andere talen als bronnen beschikbaar om nieuwe manieren van schrijven, spreken en zingen te creëren. ${ }^{62}$ De nieuwe media is een transnationaal platform waar alternatieve lokale identiteiten gecreëerd worden en waar jongeren onder elkaar telkens nieuwe normen creëren hoe 'taal' te produceren en te reproduceren. ${ }^{63}$

Ook in het spreken met elkaar laten recente ontwikkelingen in Europa zien dat jongeren in stedelijke omgevingen zoals in de Randstad, Berlijn, Kopenhagen, Londen, Oslo, Stockholm voor hun groepsidentificaties, nieuwe variaties en veranderingen aanbrengen. ${ }^{6}$ In de stedelijke jongerenvariëteiten verdwijnt bijvoorbeeld het onzijdig grammaticaal geslacht en worden woorden als meisje en buis vaak vervoegd met het bepaald lidwoord de in plaats van het. ${ }^{6}$ Dat talige veranderingen niet lukraak plaatsvinden, blijkt uit het feit dat precies dezelfde ontwikkelingen ook elders optreden die in dit kenmerk op het Nederlands grammaticaal systeem lijken zoals in de stedelijke jongerenvariëteiten van het Zweeds en Deens. In het Zweeds en Deens maakt het onzijdig lidwoord et 'een' plaats voor het zijdig lidwoord en 'een': 66

Figuur 2: Het verdwijnen van het onzijdig lidwoord ten gunste van het zijdig lidwoord

\begin{tabular}{|ll|}
\hline $\begin{array}{l}\text { Randstedelijk Nederlands } \\
\text { onzijdig } \\
\text { het huis } \\
\text { het meisje }\end{array}$ & $\begin{array}{l}\text { verdwijnt voor het zijdig lidwoord: } \\
\text { de huis } \\
\text { de meisje }\end{array}$ \\
\hline $\begin{array}{l}\text { Kopenhagen } \\
\text { onzijdig } \\
\text { et job } \\
\text { det der blad }\end{array}$ & $\begin{array}{l}\text { verdwijnt voor het zijdig lidwoord: } \\
\text { en job 'een baan' } \\
\text { den der blad }\end{array}$ \\
\hline $\begin{array}{l}\text { Stockholm } \\
\text { onzijdig } \\
\text { ett bord 'een tafel' }\end{array}$ & \\
& $\begin{array}{l}\text { verdwijnt voor het zijdig lidwoord: } \\
\text { en bord }\end{array}$ \\
\hline
\end{tabular}

Een tweede voorbeeld is dat ZEER incidenteel in de stedelijk jongerenvariëteit zinnen voorkomen als 'Toen we hadden twee auto's' in plaats van 'Toen hadden we twee auto's'. In deze zinnen staat het verbogen werkwoord hadden niet langer op de

\footnotetext{
${ }^{61}$ Androutsopoulos (2006)

${ }^{62}$ Auer \& Schmidt (20 I I: xii)

${ }^{63}$ Jacquemet (2OI I), Leppänen (2OII)

${ }^{6}$ Hewitt ( 9866$)$

${ }_{5}^{6}$ Cornips \& Hulk (2008, to appear)

${ }^{66}$ Voor randstedelijk Nederlands, zie Cornips (2002, 2008); voor Kopenhagen, zie Quist (2008); voor Stockholm, zie Kotsinas (200I:150)
} 
tweede positie in de hoofdzin. Dit verschijnsel, namelijk dat het verbogen werkwoord op de derde plaats staat in plaats van op de tweede plaats, komt in tegenstelling tot het Nederlands zeer veelvuldig voor in de stedelijke jongerenvariëteiten van het Duits, Zweeds en Noors. Grammaticale restricties worden dus opgeheven in identiteitswerk. Maar toch hier zien we ook grammatica aan het werk. Deze volgorde kan alleen maar optreden indien op de eerste positie een bijwoord staat zoals toen en op een tweede positie een onderwerp in de vorm van een persoonlijk voornaamwoord als wij. Hoe het kan dat het Nederlands in zijn grammatica veel strikter is ten aanzien van dit verschijnsel dan de andere talen roept om een taalkundige verklaring: ${ }^{67}$

Figuur 3: Het verborgen werkwoord op de derde positie in de hoofdzin

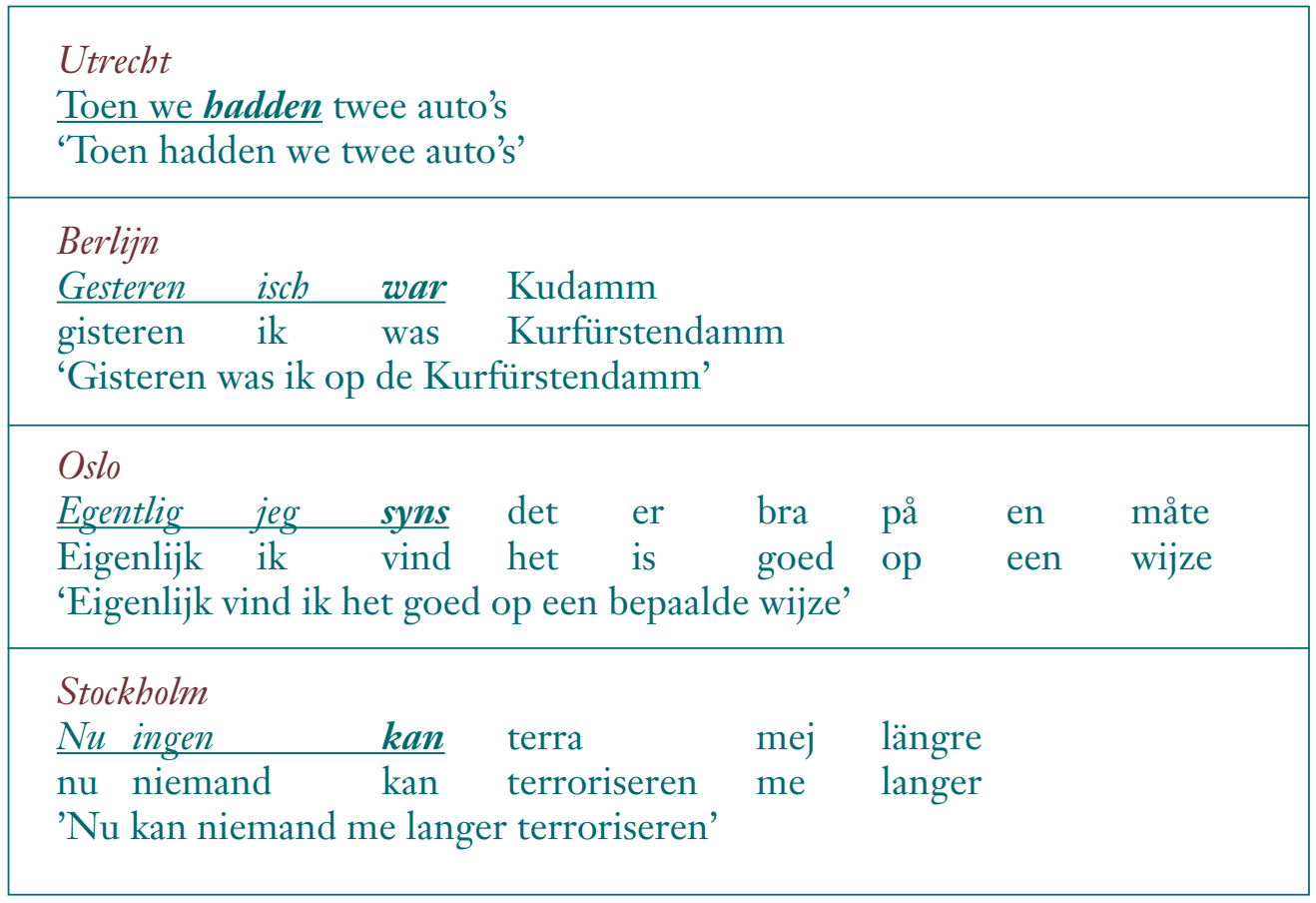

Daarnaast zijn deze veranderingen interessant omdat het laat zien dat het kenmerken zijn die een gelijke verandering ondergaan ongeacht de 'taal' waaraan we ze toeschrijven. Het roept de vraag op of deze ontwikkelingen zich ook voordoen in stedelijke omgevingen in Limburg waar het spreken van dialect van belang is.

Eveneens laten nieuwe ontwikkelingen zien dat jongeren in stedelijke omgevingen steeds meer aan 'veeltalen' doen net als de ex-mijnwerkers die Cité-Duits 
spreken. Zij maken voor groepsidentificaties en voor het eigen maken van een plek gebruik van elementen die met diverse talen geassocieerd worden. Zij hoeven daarvoor niet noodzakelijkerwijs een grondige kennis van die talen te hebben. Ook beschouwen zij dit proces van 'veeltalen' niet als taalmenging. ${ }^{68}$ Het proces van 'veeltalen' maakt de gepercipieerde grenzen tussen talen en dialecten ongedaan. Dat de jongeren aan 'veeltalen' doen en hybride taalvariëteiten gebruiken wil niet zeggen dat zij niet in staat zijn om het dialect of het Nederlands als een eentalige spreker te gebruiken. Het verschijnsel 'veeltalen' getuigt net als het eentalig spreken van een dialect of standaardtaal of van nieuwe taalvariaties van talige competenties.

Kinderen verwerven de functies en de sociale betekenis van talige vormen en combinaties ervan door in sociale activiteiten te participeren. Zo blijkt uit observatie in Valkenburg dat de zwemjuffrouw tegen een vijfjarige Nederlands spreekt zodra het kind het water ingaat maar dialect zodra het kind het water uitkomt. ${ }^{69}$ Uit observatie op een VMBO school in Geleen blijkt dat docenten het dialect in een klassikale setting inzetten om grapjes te maken of om autoriteit te claimen en in een persoonlijke relatie om het vertrouwen van de leerling te wekken. Elke talige vorm ongeacht met welke taal of dialect het geassocieerd wordt, kan een specifieke functie en sociale betekenissen krijgen en dienen in groepsidentificaties.

\section{Het belang van de leerstoel 'Taalcultuur in Limburg'}

Het belang van de leerstoel 'Taalcultuur in Limburg' is groot. Enerzijds maakt de leerstoel de betrokkenheid van de universiteit met de regio zichtbaar, anderzijds wordt door de academische inbedding een brede visie ontwikkeld over hoe algemene processen een eigen vorm krijgen in de dynamische taalcultuur op het lokale niveau. Deze kennisoverdracht zorgt ervoor dat de Limburgse eigenheid het anekdotische, stereotype beeld overstijgt. ${ }^{\circ}$ Vanuit de leerstoel is enerzijds onderzoek naar en kennisoverdracht mogelijk over hoe kinderen meerdere variëteiten als dialect en Nederlands verwerven en op welke wijze zij dit doen in vergelijking met zogenaamde eentalige kinderen. Anderzijds is kennisoverdracht en inzicht mogelijk over de functies en sociale betekenissen van hybride variëteiten en de talige competenties die daarvoor nodig zijn.

De erkenning van het Limburgs als streektaal door de Nederlandse overheid in I 997 onder deel II van het Europees Handvest voor regionale talen en talen van minderheden ${ }^{71}$ is van essentiële betekenis voor de emancipatie van het dialect als spreektaal. De Limburgse streektaal is niet taalkundig te definiëren maar wel sociaal-cultureel in de zin dat mensen zich door dat taalgebruik als een gemeenschap beleven, er waardering voor hebben en diepe gevoelens voor koesteren. ${ }^{72}$ Dit ge-

\footnotetext{
${ }^{68}$ Polylanguaging', zie Blommaert \& Rampton (20I I), Jørgensen (2008), Jørgensen et.al. (20I I), Madsen et.al. (20 IO), Rampton (2005)

${ }^{69}$ Fijnault (20 I I)

${ }^{70}$ Cornips, Leerssen, De Rooij \& Stengs (2009)

${ }^{71}$ Belemans (2009), Van Hout \& Van de Wijngaard (2006)

${ }^{72}$ Christensen (2009)
} 
meenschapsgevoel is van niet van bovenaf te regelen. Voor een breed gedragen saamhorigheidgevoel hoort van bovenaf geen normering thuis dat kwalificaties als 'zuiver' of 'fout' dialect met zich meebrengt dat sprekers in- en uitsluit op basis van hoe iemand zijn of haar dialect spreekt, en laat staan, schrijft. Normering en bijbehorende kwalificaties vanuit de dominante domeinen karakteriseren sprekers en dialect in stilstand, vastgeklonken aan één plek. Maar mensen zijn voortdurend in beweging en zijn meertalig. Om met de huidige ontwikkelingen mee te groeien in een spanningsveld van standaardisering van het Nederlands, hebben sprekers in alle rangen en standen èn hun minderheidstalen alle ruimte, zelfverzekerdheid en plezier nodig om op alle manieren mee te kùNNEN bewegen. Onderzoek naar taalcultuur betekent onderzoek naar en aandacht voor de volledige talige rijkdom in Limburg. Hoe beter we ons met alle talige vormen in alle verscheidenheid kunnen identificeren, hoe vitaler de taalcultuur in Limburg.

\section{Tot slot}

Tot slot mijn dankwoord. De bijzondere leerstoel die ik mag bekleden en de bijbehorende promotieplaats is financieel mogelijk gemaakt door de provincie Limburg. Ik ben de provincie dan ook zeer erkentelijk. Ik ben ook het bestuur van de Stichting Wetenschapsbeoefening van de Universiteit Maastricht zeer erkentelijk voor mijn benoeming tot bijzonder hoogleraar Taalcultuur in Limburg, evenals alle anderen die aan mijn benoeming en instelling van deze leerstoel bijgedragen hebben.

De leerstoel hoort thuis bij de Faculteit Cultuur- en Maatschappijwetenschappen. Vanaf het eerste moment heb ik een gastvrij onthaal gehad en wel in het bijzonder bij de capaciteitsgroep Letteren en Kunst. Naast mijn collega's in de Faculteit hebben decaan Rein de Wilde en de voormalige voorzitter van de capaciteitsgroep Wiel Kusters, in het bijzonder, deze vreemde maar in de woorden van Rein 'prettige eend' in de UM vijver welkom geheten en voel ik me hier bijzonder op mijn plek. Ik hoop dan ook veel te kunnen samenwerken.

Er zijn te veel collega's om op te noemen die ik wil bedanken met wie ik intensief heb samengewerkt en nog samenwerk in Nederland en daarbuiten op het gebied van kindertaalverwerving, sociolinguïstiek, methodologie en syntactische variatie. Er zijn echter twee collega's met wie ik het interdisciplinair onderzoek naar 'Taalcultuur in Limburg' tot nu intensief uitgedacht en vormgegeven heb. Aan Vincent en Irene, ik kan niet vaak genoeg zeggen met hoeveel plezier ik met jullie samenwerk en hoeveel resultaat dat plezier oplevert. Ik hoop dat dit gezamenlijk onderzoek nog lang mag duren. Lotte Thissen, 'mijn' promovenda; ik verheug me op ons verder gezamenlijk Limburgs avontuur. 
Dan wil ik iedereen bedanken met wie ik vanaf de instelling van de leerstoel gesprekken heb gehad. Dat zijn boeiende en stimulerende ontmoetingen met mensen uit de dialectwereld, de museumwereld, de kunstenaarswereld, de minderhedenwereld, de documentairewereld, de vrijwilligerswereld en de journalistieke wereld. Door al deze interacties krijgt deze spiksplinternieuwe leerstoel vorm en een herkenbaar gezicht. Deze ontmoetingen maken voor mij de uitoefening van deze leerstoel aan de UM zo bijzonder omdat bij iedereen een enorme passie en liefde voor Limburg en voor het eigen werk doorklinkt. Ik hoop dan ook nog veel en vaak van deze ontmoetingen te mogen hebben.

Dan het persoonlijke dankwoord. Ik dank uit mijn hart mijn ouders die er helaas niet meer zijn, evenals mijn schoonouders en vooral mijn broer Ton en mijn zus Margo die van deze gebeurtenis een nog groter feest gemakt zou hebben dan dat het al is. Mijn laatste woord is natuurlijk voor jou Méland. Jij maakt van zeer nabij de gevolgen mee van een veel reizende maar vooral pendelende partner van Amsterdam-Oost naar Maastricht. Als ik spreek over het eigen en vertrouwd maken van een plek, dan is dat noch in Amsterdam, noch in Maastricht maar daar waar jij bent.

Ik heb gezegd.

\section{Gebruikte bronnen}

Androutsopoulos, Jannis

2006 Introduction: Sociolinguistics and computer-mediated communication. Fournal of Sociolinguistics Io(4): 419-438.

Androutsopoulos, Jannis

20 I I Language and space in media discourse. In: P. Auer \& J.E. Schmidt (eds.), Language and Space. An international handbook of linguistic variation. Theories and methods, 740-759. Berlin: Mouton de Gruyter.

Auer, Peter

2005 Europe's sociolinguistic unity, or: A typology of European dialect/standard constellations. In: N. Delbecque, J. van der Auwera \& D. Geeraerts (eds.), Perspectives on variation, 7-44. Berlin: Mouton de Gruyter.

Auer, Peter \& Jürgen Erich Schmidt

20 I Introduction. In: P. Auer \& J.E Schmidt (eds.), Language and Space. An international handbook of linguistic variation. Theories and methods. Berlin: Mouton de Gruyter. 
Auer, Peter, Frans Hinskens \& Paul Kerswill

2005 The study of dialect convergence and divergence: methodological considerations. In: P. Auer, F. Hinskens \& P. Kerswill (eds.), Dialect change. Convergence and divergence in European languages, I-50. Cambridge: Cambridge University Press.

Bael, Joan

20 IO Shifting borders and shifting regional identities. In: C. Llamas \& D. Watt (eds.), Language and identities, 217-226. Edinburgh: Edinburgh University Press.

Bakkes, Pierre

1996 Variatie en verandering in het Montforts. Taalstructurele en sociolinguïstische aspecten van een veranderend dorpsdialect. Amsterdam: P. J. Meertens-Instituut.

Barbiers, Sjef, Hans Bennis, Gunther De Vogelaer, Magda Devos \& Margreet van der Ham

2005 Syntactische Atlas van de Nederlandse dialecten (SAND), Deel I. Amsterdam: Amsterdam University Press.

Barbiers, S., L. Cornips \& S. van der Kleij (red.)

2002 Syntactic Microvariation. Electronic publication of the Meertens Instituut. http://www.meertens.knaw.nl/projecten/sand/synmic/

Barbiers, Sjef, Johan van der Auwera, Hans Bennis, Eefje Boef, Gunther De Vogelaer \& Margreet van der Ham

2008 Syntactische Atlas van de Nederlandse dialecten (SAND), Deel II. Amsterdam: Amsterdam University Press.

Belemans, Rob

2002 Eindrapport over de Limburg-enquête. Leuven: KU Leuven.

Belemans, Rob

2009 Taal of tongval?: de gespleten Limburgse kus, oraal erfgoed en taalpolitiek. Brussels: Pharo.

Bennis, H., L. Cornips \& M. van Oostendorp

2004 Verandering en verloedering. Normen en waarden in het Nederlands. Amsterdam: Amsterdam University Press.

Blommaert, Jan 2010 The sociolinguistics of globalization. Cambridge: Cambridge University Press.

Blommaert, Jan

20 I Supervernaculars and their dialects. Tilburg Papers in Culture Studies 9.

Blommaert, Jan \& Ben Rampton

20 I Language and superdiversity. Language and superdiversities I3(2): I-22.

Bree, Cor, van I996 Historische taalkunde. Tweede druk. Leuven/Amersfoort: Acco.

Brubaker, Rogers \& Frederick Cooper

2000 Beyond Identity. Theory and Society 29: I-47. 
2005 Identity and interaction: a sociocultural linguistic approach. Discourse Studies, 7(4-5): 585-614.

Bucholtz, Mary \& Kira Hall

2008 All of the above: New coalitions in sociocultural linguistics. Fournal of Sociolinguistics I 2(4): 4OI-43I.

Chambers, Jack K. \& Peter Trudgill

I998 Dialectology. Tweede druk. Cambridge University Press.

Christensen, Ann-Dorte

2009 Belonging and Unbelonging from an Intersectional Perspective. Gender Technology and Development I 3(I): 2 I-4I.

Cornips, Leonie

I994 Syntactische variatie in het Algemeen Nederlands van Heerlen. Ongepubl. dissertatie, Universiteit van Amsterdam, IFOTT 6.

Cornips, Leonie

2002 Etnisch Nederlands in Lombok. In: H. Bennis, G. Extra \& J. Nortier (red.), Een buurt in beweging. Talen en Culturen in het Utrechtse Lombok en Transvaal, 285-302. Amsterdam: Stichting beheer IISG.

Cornips, Leonie 2003/20 2 Heerlens Nederlands. Taal in stad en land, Eerste druk. Tweede druk, Heerlen: Gemeente Heerlen, bij gelegenheid van het uitvaren van de 62e Togh van het Gilde Blauw Sjuut.

Cornips, Leonie

2006 Intermediate Syntactic Variants in a Dialect - Standard Speech Repertoire and Relative Acceptability. In: G. Fanselow, C. Féry, M. Schlesewsky \& R. Vogel (eds.), Gradience in Grammar. Generative Perspectives, 85-105. Oxford: Oxford University Press.

Cornips, Leonie

2008 Loosing grammatical gender in Dutch. The result of bilingual acquisition and/ or an act of identity? International fournal of Bilingualism - Ethnolects? The emer-

Cornips, Leonie gence of new varieties among adolescents I2(I-2): I05-I24.

$20 \mathrm{I} 2$ Eigen en vreemd. Meertaligheid in Nederland. Amsterdam: Amsterdam University Press.

Cornips, Leonie

to appear Recent developments in Limburg. In: F. Hinskens \& J. Taeldeman (eds.), Language and Space: Dutch. Berlin: Mouton de Gruyter.

Cornips, Leonie \& Karen P. Corrigan

2005 a Toward an integrated approach to syntactic variation: a retrospective and prospective synopsis. In: L. Cornips \& K.P. Corrigan (eds.), Syntax and Variation. Reconciling the Biological with the Social, I-27. Amsterdam/Philadelphia: John Benjamins. 
2005b Convergence and Divergence in Grammar. In: P. Auer, F. Hinskens \& P. Kerswill (eds.), Dialect change. Convergence and divergence in European languages, 96-I 34. Cambridge: Cambridge University Press.

Cornips, Leonie \& Aafke Hulk

2006 External and Internal Factors in Bilingual and Bidialectal Language Development: Grammatical Gender of the Dutch Definite Determiner. In: C. Lefebvre, L. White \& C. Jourdan (eds.), L2 Acquisition and Creole Genesis. Dialogues, 355-378. Amsterdam/Philadelphia: John Benjamins.

Cornips, Leonie \& Aafke Hulk

2008 Factors of success and failure in the acquisition of grammatical gender in Dutch. Second Language Research 24(3): 267-296.

Cornips, Leonie \& Aafke Hulk

to appear Late child acquisition and identity construction: variation in use of the

Dutch definite determiners de and het. In: P. Auer, et.al., Language variation

European Perspectives IV -Studies in Language Variation. Amsterdam: John Benjamins Publishing.

Cornips, Leonie, Jürgen Jaspers \& Vincent de Rooij

to appear The politics of labelling youth vernaculars in the Netherlands and Belgium.

Multilingual urban sites. In: J. Nortier \& B.A. Svendsen (eds.), Structure, Activity and Ideology. Cambridge: Cambridge University Press.

Cornips, Leonie, Joep Leerssen, Vincent de Rooij \& Irene Stengs

2009 Between Nostalgia and Subversion: Language, Language Difference, and the Construction of Cultural Heritage in Limburg. NWO aanvraag Culturele Dynamiek.

Cornips, Leonie \& Vincent De Rooij

in press. Selfing and othering through categories of race, place, and language among minority youths in Rotterdam, The Netherlands. In: P. Siemund, I. Gogolin, J. Davydova \& Monika Schulz (eds.), Multilingualism and language contact in urban areas: Acquisition - Development - Teaching - Communication. Amsterdam: John Benjamins.

Cornips, Leonie, Vincent de Rooij \& Irene Stengs

te versch. Carnavalesk taalgebruik en de constructie van lokale identiteiten. Een pleidooi voor taalcultuur als onderzoeksveld. Dutch Journal of Applied Linguistics (DufAL). Amsterdam: Benjamins.

Cornips, Leonie \& Irene Stengs

20 IO Regionale identiteit: het belang van het lokale voor de beleving van wie we zijn. Idee: wetenschappelijk tijdschrift D66 3 I (5): IO-I 3.

Coupland, Nicolas

2002 Language, situation, and the relational self. In: P. Eckert \& J. Rickford (eds.), Style and sociolinguistic variation, I85-2 IO. Cambridge: Cambridge University Press. 
De Schutter, Georges, Boudewijn van den Berg, Ton Goeman \& Thera de Jong

2005 Morfologische atlas van de Nederlandse dialecten (MAND), Deel I. Amsterdam: Amsterdam University Press.

Dirkx, Merel

$20 \mathrm{I}$ Verwerving van grammaticaal geslacht in Limburg. Door Nederlands eentalige, dialectsprekende en anderstalige kinderen. MA-scriptie UvA/Meertens Instituut.

Driessen, Geert

2006 Ontwikkelingen in het gebruik van streektalen en dialecten in de periode 1995-2003. Toegepaste Taalwetenschap in Artikelen 75: 103-I I3.

Duyvendak, Jan Willem

$20 \mathrm{I}$ The politics of home: belonging and nostalgia in Europe and the United States. Palgrave: Basingstoke.

Eckert, Penelope

2000 Linguistic Variation as Social Practice. Oxford: Blackwell.

Eckert, Penelope

2004 Variation and a sense of place. In: C. Fought (ed.), Sociolinguistic Variation. Critical reflections, I07-I I 8. Oxford: Oxford University Press.

Eckert, Penelope

2008 Variation and the indexical field. Fournal of Sociolinguistics I 2(4), 453-476.

Eckert, Penelope

20I I Who's there? Language and space in social anthropology and interactional sociolinguistics. In: P. Auer \& J.E. Schmidt (eds.), Language and Space. An international handbook of linguistic variation. Theories and methods, I63-I 78 . Berlin: Mouton de Gruyter.

Extra, Guus

2004 Taal en identiteit. De vitaliteit van minderheidstalen in vergelijkend perspectief. Taal en Tongval 56(1 7): 109-I34.

Extra, Guus \& Durk Gorter

200 I Comparative perspectives on regional and immigrant minority languages in multicultural Europe. In: G. Extra \& D. Gorter (eds.), The other languages of Europe, I-44. Clevedon: Multilingual Matters.

Fijnault, Charlotte

20I I 'Do rieen ze os van de sukke aaf!' Onderzoek naar de taalkeuze van dialectsprekende kinderen in Limburg. Ma-scriptie Meertens Instituut/UU.

Freywald, Ulrike, Leonie Cornips, Natalia Ganuza, Ingvild Nistov \& Toril Opsahl

to appear Beyond verb second - a matter of novel information structural effects? Evidence from Norwegian, Swedish, German and Dutch. In: J. Nortier \& B.A. Svendsen (eds.), Multilingual urban sites. Structure, Activity and Ideology. Cam-

Gal, Susan bridge: Cambridge University Press.

20 I I Language and political spaces. In: P. Auer \& J.E. Schmidt (eds.), Language and Space. An international bandbook of linguistic variation. Theories and methods, 3349. Berlin: Mouton de Gruyter. 
Gal, Susan \& Judith T. Irvine

I995 The boundaries of languages and disciplines: How ideologies construct difference. Social Research 62(4), 967-1001.

Giesbers, Herman

I989 Code-switching tussen dialect en standaardtaal. Ongepub. proefschrift Universiteit van Nijmegen/P.J.-Meertens Instituut, Amsterdam.

Goeman, Ton, Marc van Oostendorp, Pieter van Reenen, Oele Koornwinder, Boudewijn van den Berg \& Anke van Reenen

2008 Morfologische atlas van de Nederlandse dialecten (MAND), Deel II. Amsterdam: Amsterdam University Press.

Goossens, Jan \& Jacques Van Keymeulen

2006 Geschiedenis van de Nederlandse dialectstudie. Toponymie \& Dialectologie LXXVIII: 37-97. Bron DBNL 2002.

Haugen, Einar

I997[1966] Language standardization. Reprint. In: N. Coupland \& A. Jaworksi (eds.), Sociolinguistics. A reader, 34I-352. New York: St. Martin's Press.

Heller, Monica

20I I Language as a process: a study on transnational spaces. In: P. Auer \& J.E. Schmidt (eds.), Language and Space. An international handbook of linguistic variation. Theories and methods, 724-740. Berlin: Mouton de Gruyter.

Hermans, Ben

to appear Phonological features of Limburg dialects. Recent developments in Limburg. In: F. Hinskens \& J. Taeldeman (eds.), Language and Space: Dutch. Berlin: Mouton de Gruyter.

Hewitt, Roger

I986 White talk black talk. Inter-racial friendship and communication amongst adolescents. Cambridge: Cambridge University Press.

Hinskens, Frans

I993 Dialect levelling in Limburg. Structural and sociolinguistic aspects. Ongepub. proefschrift, Universiteit van Nijmegen.

Hymes, Dell

I974 Foundations in sociolinguistics. An ethnographic approach. Philadelphia: University of Pennsylvania Press.

Irvine, Judith T.

200 I Style as distinctiveness: the culture and ideology of linguistic differentation. In: P. Eckert \& J. Rickford (eds.), Style and sociolinguistic variation, 2 I-43. Cam-

Jacquemet, Marco bridge: Cambridge University Press.

2005 Transidiomatic practices: Language and power in the age of globalization. Language and Communication 25: 257-277. 
20 I Language and transnational spaces. In: P. Auer \& J.E. Schmidt (eds.), Language and Space. An international handbook of linguistic variation. Theories and methods,

Jaspers, Jürgen 50-69. Berlin: Mouton de Gruyter.

2005 Tegenwerken, belachelijk doen. Talige sabotage van Marokkaaanse jongens op een Antwerpse middelbare school. Brussel: VUBPress.

Johnstone, Barbara

2004 Place, Globalization and Linguistic Variation. In: C. Fought (ed.), Sociolinguistic variation. Critical Reflections, 65-83. Oxford: Oxford Press.

Johnstone, Barbara

20 IO Indexing the local. In: N. Coupland (ed.), The handbook of language and globalization, 386-405. Malden, Mass: Wiley-Blackwell.

Johnstone, Barbara

20 i ra Language and Place. In: R. Mesthrie (ed.), Cambridge Handbook of Sociolinguistics. Cambridge: Cambridge University Press.

Johnstone, Barbara

20 I r Language and geographical space. In: P. Auer \& J.E. Schmidt (eds.), Language and Space. An international handbook of linguistic variation. Theories and methods, I-I 7. Berlin: Mouton de Gruyter.

Jørgensen, J. Normann

2008 Languaging; Nine years of poly-lingual development of young Turkish-Danish grade school students, volume I. Copenhagen: University of Copenhagen.

Jørgensen, J. Normann, Martha S. Karrebæk, Lian Malai Madsen \& Janus Spindler Møller 20 I I Polylanguaging in superdiversity. Language and superdiversities I 3(2): 23-38.

Joseph, John

2010 Identity. In: C. Llamas \& D. Watt, Language and identities, 9-1 7. Edinburgh: Edinburgh University Press.

Kessels-van der Heijde, Marina

2002 Maastricht, Maestricht, Mestreech. De taalverhoudingen tussen Nederlands, Frans en Maastrichts in de negentiende eeuw. Hilversum: Verloren.

Knotter, Ad (red.)

2009 Dit is Limburg. Opstellen over de Limburgse identiteit. Sociaal Historisch Centrum voor Limburg: Waanders Uitgeverij.

Knotter, Ad

2009 Limburg bestaat niet. Paradoxen van een sterke identiteit. In: Ad Knotter

Knotter, Ad (red.), Dit is Limburg! 263-277.

$20 \mathrm{I}$ Regional character and regional stereotypes: some thoughts about their construction in Dutch Limburg. Lezing gehouden tijdens NIAS symposium 'Constructie van locale identiteit door taal en cultuur'. Wassenaar, I December. 
200 I Pidginization, creolization and creoloids in Stockholm, Sweden. In: N. Smith \& T. Veenstra (eds.), Creolization and Contact, I 25-I 56. Amsterdam: John Benjamins.

Kroon, Sjaak \& Ton Vallen (red.)

2004 Dialect en school in Limburg. Amsterdam: Aksant Academic Publishers.

Kroskrity, Paul V.

2000 Regimes of language: ideologies, polities and identities. Santa Fe: School of American Research Press.

Labov, William

I966 The social stratification of English in New York City. Washington: Center for Applied Linguistics.

Labov, William

I972 Sociolinguistic Patterns. Philadelphia: University of Pennsylvania Press.

Labov, William

I994 Principles of linguistic change. Internal factors. Oxford: Blackwell.

Leerssen, Joep

1999 Nationaal denken in Europa. Een cultuurbistorische schets. Amsterdam: Amsterdam University Press.

Leppänen, Sirpa

20 I I Linguistic and generic hybridity in web writing. The case of fan fiction. In: M.

Sebba, M. Shahrzad \& C. Jonsson (eds.), Language Mixing and Code-switching in Writing: Approaches to Mixed-language Written Discourse, 233-254. London: Routledge.

Madsen, Lian Malai, Janus Spindler Møller \& J. Normann Jørgensen

20 IO Street language and integrated. In: L.M. Madsen, J.S. Møller \& J.N. Jørgensen (eds.), Language use and enregisterment among late modern urban girls. Ideological constructions and enregisterment of linguistic youth styles. Copenhagen studies in bilingualism, vol. 55. University of Copenhagen.

Marynissen, Ann

2004 Limburgers worden Nederlanders? Over de vernederlandsing van het zuidoosten van Nederlands Limburg (I 789-1935). Taal \& Tongval I 7: 64-85.

Mathijsen, Marita

20 I De Limburger als de ander. Letterkundig Centrum Limburg.

Milroy, James

200 I Language ideologies and the consequences of standardization. Fournal of Sociolinguistics 5: 530-555.

Notten, Jan G.M.

I988 De chinezen van Nederland. Tweede herziene druk. Valkenburg: Valkdruk BV.

Orbons, Piet \& Lou Spronck

I966[2009] Limburgers worden Nederlanders. Een moeizaam integratieproces. In: A. Knotter (red.), Dit is Limburg. Opstellen over de Limburgse identiteit, 33-6o. Sociaal Historisch Centrum voor Limburg: Waanders Uitgever. 
Palmen, Connie

I995 Vertalen is mijn woord. Maatstaf 9-10: 48-50.

Paulissen, Saskia

20 I Taalgebruik onder Limburgse jongeren. MA-Stageverslag. Meertens Instituut/UvA.

Preston, Dennis R.

2002 Language with an attitude. In: J. Chambers, et.al., The Handbook of Language Variation and Change, 40-66. Malden: Blackwell.

Quist, Pia

2008 Sociolinguistic approaches to multiethnolect. International fournal of Bilingualism - Ethnolects? The emergence of new varieties among adolescents I 2(I-2): 43-62.

Quist, Pia

20 I I Untying the language-body-place connection: A study on linguistic variation and social style in a Copenhagen community of practice. In: P. Auer \& J.E. Schmidt (eds.), Language and Space. An international handbook of linguistic variation. Theories and methods, 632-648. Berlin: Mouton de Gruyter.

Rampton, Ben

2005[1995] Crossing: Language and ethnicity among adolescents (Second Edition). Manchester: St. Jerome Publishing.

Silverstein, Michael

I985 Language and the culture of gender. In: E. Mertz \& R. Parmentier (eds.), Semiotic Mediation, 2 19-259. New York: Academic Press.

Structuurrapport bijzondere leerstoel 'Taalcultuur in Limburg'

2010 in te stellen door de Provincie Limburg bij de Faculteit Cultuur- en Maatschappijwetenschappen van Maastricht University.

Van de Beek, Johan \& Paul Gageldonk

$20 \mathrm{I} 2$ Het onbehagen: een zoektocht naar de Limburgse ziel. Sittard: Media Groep Limburg.

Van der Horst, Joop \& Kees

I999 Geschiedenis van het Nederlands in de twintigste eeuw. Den Haag: SDU.

Van Hout, Roeland \& Ton van de Wijngaard (red.)

2006 Lang leve de dialecten. Streektaalbeleid in Nederland. Maastricht: Raod veur 't Limburgs/Uitgeverij TIC.

Venner, Jos

$200 \mathrm{I}$ Geschiedenis van Limburg. Deel II. Maastricht: LGOG.

Wijers, Carla

I995 Prinsen \& clowns in het Limburgse narrenrijk. Het carnaval in Simpelveld en Roermond 1945-1992. Amsterdam: P.J.Meertens-Instituut.

Wijers, Carla

2009 In één hand de rozenkrans, in de andere hand een glas bier. De Limburgse identiteit onder de loep. In: Ad Knotter (red.), I 27-I 50.

Wöltgens, Thijs

I995 De Limburgse waarheid. Maatstaf 9-ıо: I9. 